\title{
Phytosociological Survey of Weeds in Cultivars of Common Beans With Different Types of Growth IN THE NORTH OF MINAS GERAIS ${ }^{1}$
}

\author{
Levantamento Fitossociológico de Plantas Daninhas em Cultivares de Feijão-Comum de \\ Diferentes Tipos de Crescimento, no Norte de Minas Gerais
}

BATISTA, P.S.C. ${ }^{2}$, OLIVEIRA, V.S. ${ }^{2}$, CAXITO, A.M. ${ }^{3}$, CARVALHO, A.J. ${ }^{2}$, and ASPIAZÚ, I. ${ }^{2}$

\begin{abstract}
The objective of this paper was to characterize the phytosociology of weeds in function of different types of growth of common bean cultivars in the North of Minas Gerais. The study was conducted in the experimental area, located in the municipality of Janaúba, MG. The treatments consisted of eight commercial cultivars of common beans with different types of growth. The design was done in randomized blocks, with three replications. The soil preparation was conventional and the planting was done in June, with manual seeders, with a $0.5 \mathrm{~m}$ spacing between rows. The phytosociological survey was performed in two phases of bean cultivation, in stages V3 and R8. The method used was the square inventory one, with a $0.25 \mathrm{~m}^{2}$ frame, randomly released once in each plot. Samples of each square were identified and quantified by family, genus and species, and the sampled plants were collected with their complete structure. Next, the material was sent to a drying greenhouse with forced air circulation at $65{ }^{\circ} \mathrm{C}$ for 72 hours, for drying and determination of weight of dry matter. We also estimated the Relative Frequency, Relative Density and Relative Abundance to determine the importance value index and similarity index. At the V3 stage, the species Sorghum halepense, Brachiaria plantaginea and Boerhavia diffusa had higher importance value indexes. At the R8 stage, the Amaranthus viridis specie showed higher importance value index and dry matter. In more prostrate cultivars, the weeds present lower importance value indexes at the R8 stage.
\end{abstract}

Keywords: Phaseolus vulgaris, phytosociological, plant habit.

\begin{abstract}
RESUMO - Objetivou-se com este trabalho caracterizar a fitossociologia de plantas daninhas em função de diferentes tipos de crescimento de cultivares de feijão-comum, no norte de Minas Gerais. O trabalho foi realizado em área experimental, localizada no municipio de Janaúba, MG. Os tratamentos consistiram de oito cultivares comerciais de feijão-comum de diferentes tipos de crescimento. $O$ delineamento foi em blocos casualizados com três repetições. O preparo do solo foi convencional, $e$ o plantio, realizado no mês de junho, com semeadoras manuais, no espaçamento de 0,5 $m$ entre linhas. Realizou-se o levantamento fitossociológico em duas fases de cultivo do feijoeiro, nos estádios V3 e R8. Utilizou-se o método do quadrado inventário, com quadro de 0,25 $\mathrm{m}^{2}$, lançado aleatoriamente uma vez em cada parcela. As amostras de cada quadrado foram identificadas e quantificadas por família, gênero e espécie, sendo as plantas amostradas coletadas com estrutura completa. Em seguida, o material foi encaminhado para estufa de secagem com circulação forçada de ar a $65^{\circ} \mathrm{C}$ por 72 horas, para secagem e determinação da massa da matéria seca. Foram também estimadas a frequência relativa, densidade relativa e abundância relativa, para determinação do indice de valor de importância e indice de similaridade. No estádio V3, as espécies Sorghum halepense, Brachiaria plantaginea e Boerhavia diffusa apresentaram maiores índices de valor de importância. No estádio R8, Amaranthus viridis mostrou maior indice de valor de importância e massa seca. Nos cultivares de crescimento mais prostrado, as plantas daninhas apresentaram menores indices de valor de importância no estádio R8.
\end{abstract}

Palavras-chave: Phaseolus vulgaris, fitossociologia, porte de plantas.

Recebido para publicação em 3.12.2015 e aprovado em 4.2.2016.

Universidade Estadual de Montes Claros - UNIMONTES, Janaúba-MG, Brasil, < paulosergiocardoso@yahoo.com.br>; ${ }^{3}$ Empresa de Assistência Técnica e Extensão Rural do Estado de Minas Gerais - EMATER, Janaúba-MG, Brasil. 


\section{INTRODUCTION}

Common bean (Phaseolus vulgaris) is one of the main Brazilian foods, with significant social and economic importance mainly due to its high protein value (Tavares et al., 2013). Brazil is the greatest producer of beans in the world, with an average annual production in 2014 of 2.7 million tons, and Minas Gerais is the second greatest national producer, with around 573 tons (Embrapa, 2015).

The north of Minas Gerais, even with a semiarid climate and predominance of high temperatures, low relative air humidity and irregular distribution of rain, is among the three main producers in the State. However, factors that involve competition with weeds are considered limiting to the low productivity presented by the crop (Tavares et al., 2013).

The bean plant has limited competitive capacity with the weeds and, depending on the interference degree imposed by the interaction existing between the weed community and the crop, the environmental factors and the coexistence period, the losses in productivity may range from 35 to $67 \%$ (Salgado et al., 2007; Borchartt et al., 2011). Since the bean plant is cultivated throughout the year in different crops and regions in the country, it is interfered by the wide diversity of weeds (Cobucci, 2004).

In order to outline weed management strategies in cultivated environments, it is indispensable to carry out surveys to identify and quantify the dynamics of populations of weeds in the weed community to define the best moment and the weed control method to be adopted, whether cultural, mechanic, physical, biological, chemical or integrated, because the infestation conditions and the handling options are very different (Oliveira and Freitas, 2008).

From the phytosociological survey we obtain the amount of species hierarchically distributed, related to the relative position in relation to the others, allowing the quantitative interpretation of the structure of the community and their ecological relations (Gama, 2009). The phytosociological studies compare the populations of weeds at a certain point. Scheduled repetitions of phytosociological studies may indicate variation trends of the importance of one or more populations, and these variations may be associated to the agricultural practices adopted (Oliveira and Freitas, 2008).

In the identification of weed species that are present in the area, as well as those that present greater importance, the phytosociological variables taken into account are frequency, density, abundance and importance value index (Oliveira and Freitas, 2008). The phytosociological indexes are highly important for the analysis of the impact the handling systems and agricultural practices have on the dynamics of growth and occupation of weed communities in agroecosystems (Pitelli, 2000).

After the application of the herbicide, there are weeds that resist to them, and the plants that germinate develop fast, resulting on serious problems by the end of the bean cycle, which can cause great losses in productivity and quality of grains, especially in cultivars of more erect habit, which "close" the area less than the others. Considering that, the objective of this paper was to characterize the phytosociology of the weeds in cultivars of common beans with different growth types, at stage V3 (first trifoliate leaf - before weed control) and R8 (grain filling - after weed control).

\section{MATERIAL AND METHODS}

The experiment was done in an experimental area in the city of Janaúba, MG, with the geographic coordinates of $15^{\circ} 47^{\prime} 50^{\prime \prime S}$ and $43^{\circ} 18^{\prime} 31^{\prime \prime} \mathrm{W}$ and altitude of $516 \mathrm{~m}$. The climate in the region is the "AW" type (rainy tropical, savannah with dry winter), according to Köppen. The soil was classified as Eutrophic Red Latosol.

The treatments consisted in four cultivars of erect habit (BRS Valente, BRS Notável, BRS Campeiro and BRS Radiante) and four semierect to prostrate (Pérola, BRSMG Madrepérola, BRSMG Majestoso and BRS Ouro Negro). The characteristics of the cultivars used are on Table 1 . The experimental design was done in randomized blocks, with three replications. The plots were composed of four rows of bean plant, spaced in $0.5 \mathrm{~cm}$ among each other, with $4 \mathrm{~m}$ long each. 
Table 1 - Characteristics of nine cultivars evaluated in the phytosociological survey

\begin{tabular}{|l|l|l|c|c|}
\hline \multicolumn{1}{|c|}{ Cultivar } & Commercial group & Growth habit & Growth type & Habit \\
\hline BRSMG Majestoso & Carioca & Undetermined & III & SE \\
\hline BRS Ouro Negro & Black & Undetermined & II/III & SP to PR \\
\hline Pérola & Carioca & Undetermined & II/III & SE \\
\hline BRSMG Madrepérola & Carioca & Undetermined & III & PR \\
\hline BRS Valente & Black & Undetermined & II & ER \\
\hline BRS Campeiro & Black & Undetermined & II & ER \\
\hline BRS Notável & Carioca & Undetermined & II/III & ER \\
\hline BRS Radiante & Manteigão/Rajado & Determined & I & ER \\
\hline
\end{tabular}

SE: semi erect; SP: semi prostrate; PR: prostrate; ER: erect.

The area was prepared in a conventional way, with plowing and two harrowing. After preparing the soil, a seeder-fertilizer was used for furrowing and distribution of fertilizer of planting in the rows. Planting was done in June 2014 , with the help of manual seeders, putting around 15 seeds per row meter. Fertilization consisted of $300 \mathrm{~kg} \mathrm{ha}^{-1}$ of the 04-30-10 formulation in planting, plus $40 \mathrm{~kg} \mathrm{ha}^{-1}$ of $\mathrm{N}$ in coverage, at the V4 stage, using urea as a nitrogen source. In addition, an application of $40 \mathrm{~g} \mathrm{ha}^{-1}$ of molybdenum was done on the leaf by using sodium molybdate. The crop was irrigated by conventional aspersion from planting until physiologic maturity.

The harvest of weeds was done in two periods of the phenological cycle of the crop. The first one happened at stage V3, 20 days after sowing (DAS), before the control of weeds. Right after the first harvest, the control of weeds was done with the application of herbicides fluazifop-P-butyl $\left(0.75 \mathrm{~L} \mathrm{ha}^{-1}\right)$ and fomesafen (1 L ha $\left.{ }^{1}\right)$. The second harvest was done at stage R8, at 70 DAS, due to the filling of bean plant grains.

In the harvest of plants, the inventory square standard method was used $(0.5 \mathrm{~m} \mathrm{x}$ $0.5 \mathrm{~m}$ ), and this was randomly released once in each plot, as described by Braun-Blanquet (1979) and Erasmo et al. (2004). The weeds were harvested with a complete structure, with their root system and aerial part.

The identification of species of weeds from each frame was done by comparison, according to the Lorenzi (2008) classification, and they were quantified by family, genus and species. Afterwards, the samples from each species were conditioned in paper bags and forwarded to the forced-air-circulation greenhouse at $65{ }^{\circ} \mathrm{C}$ for 72 hours, for later weighting of the dry matter in a precision scale, and the result expressed in grams.

The number of individuals per species in each cultivar and the total number per harvest was calculated. From the identification and counting of species, there was a calculation of the following phytosociological variables: absolute frequency $(\mathrm{F})$, relative frequency $(\mathrm{Fr})$, absolute density (D), relative density (Dr), absolute abundance (A), relative abundance (Ar) and importance value index (IVI), for each one of the experimental plots (Brighenti et al., 2003). The relative indexes were used for calculation of the importance value indexes, expressed constantly, and the similarity index (IS), in percentage.

In order to calculate, the following formulas were used:

$\mathrm{F}=$ no. of squares that have the species / total no. of squares obtained

$\mathrm{Fr}=\mathrm{F}$ of the species $* 100 /$ Total frequency of the species

$\mathrm{D}=$ total no. of individuals per species / total area occupied by the squares

$\mathrm{Dr}=\mathrm{D}$ of the species * $100 /$ Total density of the species

$A=$ total no. of individuals per species / total no. of squares that contain the species

$\mathrm{Ar}=\mathrm{A}$ of the species $* 100 /$ Total abundance of the species

$\mathrm{IVI}=\mathrm{Fr}+\mathrm{Dr}+\mathrm{Ar}$

IS $=[(2 * a) /(b+c)] * 100$ 
in which $a$ is the number of the species common to both sizes and/or stages; and b and $c$ the total number of species in both sizes and/ or stages compared.

\section{RESULTS AND DISCUSSION}

At stage V3, 1,116 specimens of weeds were collected, represented by 12 species, distributed into nine families (Tables 2 and 4). At stage R8, 285 specimens were collected, represented by 13 species, distributed into seven families (Tables 3 and 5). The most representative families and with greater importance value index (IVI) in both collection stages were Poaceae, Amaranthaceae, Asteraceae and Malvaceae. Santi et al. (2014), when assessing the phytosociological variability of weeds in a soy tillage area in Boa Vista das Missões, RS, observed that the families Poaceae and Asteraceae were the ones more occurring in the area. However, Cruz et al. (2009), in a study carried out in an area rotated with crops of soy, corn and rice,

Table 2 - Weeds found in crops of common beans in stage V3. Janaúba, MG. 2015

\begin{tabular}{|l|l|l|l|}
\hline \multirow{2}{*}{ Family } & \multicolumn{2}{|c|}{ Genus } & \multicolumn{2}{c|}{ Species } \\
\cline { 2 - 4 } & & \multicolumn{1}{c|}{ Scientific name } & Common name \\
\hline Amaranthaceae & Amaranthus & Amaranthus viridis & Apaga-fogo \\
\hline \multirow{2}{*}{ Asteraceae } & Alternanthera & Alternanthera tenella & Beggarticks \\
\cline { 2 - 4 } & Bidens & Bidens pilosa & Messina creeper \\
\hline Convolvulaceae & Merremia & Merremia aegyptia & Leiteiro \\
\hline Euphorbiaceae & Euphorbia & Euphorbia heterophylla & Sicklepod \\
\hline Fabaceae & Senna & Senna obtusifolia & Guanxuma \\
\hline \multirow{2}{*}{ Malvaceae } & Malvastrum & Malvastrum coromandelianum & Musk mallow \\
\cline { 2 - 4 } & Sida & Sida cordifolia & Pega-pinto \\
\hline Nyctaginaceae & Boerhavia & Boerhavia diffusa & Capim-marmelada \\
\hline \multirow{2}{*}{ Poaceae } & Brachiaria & Brachiaria plantaginea & Capim-massambará \\
\cline { 2 - 4 } & Sorghum & Sorghum halepense & Beldroega \\
\hline Portulacaceae & Portulaca & Portulaca oleracea & \\
\hline
\end{tabular}

Table 3 - Weeds found in crops of common beans in stage R8. Janaúba, MG. 2015

\begin{tabular}{|c|c|c|c|}
\hline \multirow{2}{*}{ Family } & \multirow{2}{*}{ Genus } & \multicolumn{2}{|c|}{ Species } \\
\hline & & Scientific name & Common name \\
\hline \multirow{2}{*}{ Amaranthaceae } & \multirow{2}{*}{ Amaranthus } & Amaranthus deflexus & Slender amaranth \\
\hline & & Amaranthus viridis & Slender amaranth \\
\hline \multirow{2}{*}{ Asteraceae } & Alternanthera & Alternanthera tenella & Apaga-fogo \\
\hline & Bidens & Bidens pilosa & Beggarticks \\
\hline Brasicaceae & Cleome & Cleome affinis & Spider flower \\
\hline \multirow{3}{*}{ Convolvulaceae } & Ipomoea & Ipomoea purpúrea & Common morning-glory \\
\hline & Jacquemontia & Jacquemontia heterantha & Common morning-glory \\
\hline & Merremia & Merremia aegyptia & Messina creeper \\
\hline \multirow{2}{*}{ Euphorbiaceae } & Chamaesyce & Chamaesyce hirta & Dayflowers \\
\hline & Euphorbia & Euphorbia heterophylla & Leiteiro \\
\hline Fabaceae & Senna & Senna obtusifolia & Sicklepod \\
\hline \multirow{2}{*}{ Malvaceae } & Malvastrum & Malvastrum coromandelianum & Guanxuma \\
\hline & Sida & Sida cordifolia & Musk mallow \\
\hline
\end{tabular}




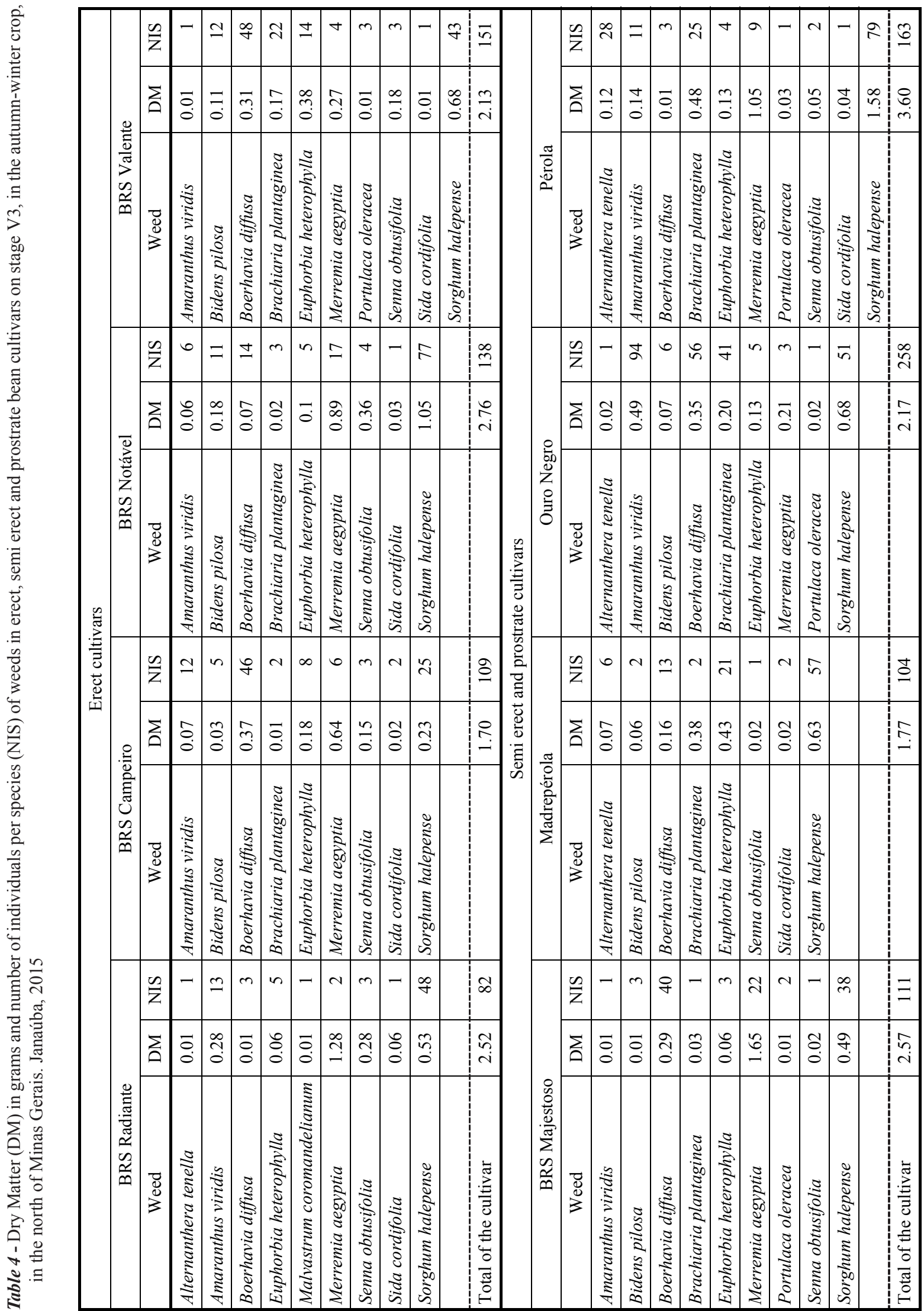




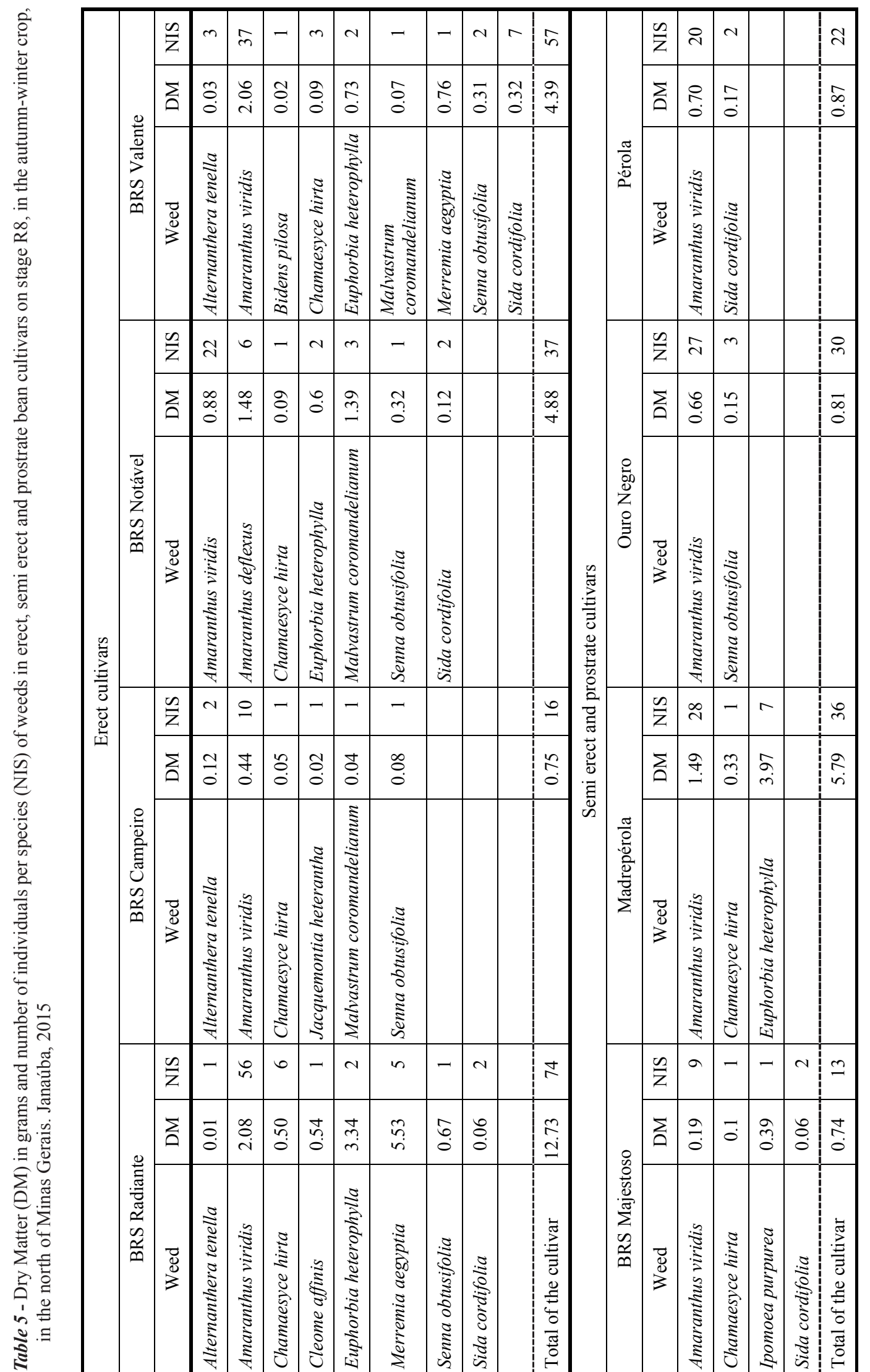


in the Roraima Cerrado, in 2009, observed that the families with more occurrence were Amaranthaceae, Euphorbiaceae and Poaceae. These results show the great importance of these families in the different cultivation systems, in different crops and regions, especially due to the aggressive potential of weeds belonging to these families.

At the V3 stage, $46.06 \%$ of the weed flora was monocots and $53.94 \%$ was dicotyledons. At the R8 stage, all weeds were identified as dicotyledons, showing their greater competitiveness in conditions of lower light incidence. Salgado et al. (2007), when assessing the interference of weeds in the carioca bean plant, with undetermined growth habit (Type III) in Jaboticabal-SP, obtained weeds composed by 13 species of weeds, $62 \%$ of them dicotyledons and $38 \%$ of monocots.

At the V3 stage, a smaller number of specimens were observed in cultivar BRS Radiante, and a greater number in cultivar Ouro Negro, 82 and 258, respectively (Table 4). Since the bean plant in this stage was beginning to develop and had not established in the area, the size of the cultivar did not influence the number of specimens and species found.

The greater number of weeds specimen in the area, in all cultivars, was found in stage V3, due to the seed bank of weeds in the area, and also because the survey at this stage was done before the control with herbicides. Sorghum halepense was the species that had greater values of relative frequency, relative density and relative abundance in this stage, showing an IVI superior to the other species of weeds in cultivars BRS Radiante, BRS Notável, BRSMG Madrepérola and Pérola, reaching values of $122.6 ; 113.5 ; 116.3$; and 97.6, respectively (Figure 1). Weed species which have greater IVI values have priority in the management of the cultivated area. These results highlighted the importance of a survey on weeds in the cultivation areas, since it leads to the adoption of a better management and to species that need more control.

The high importance of the species $S$. halepense in the initial phase of the bean may be related to the fact that the crop before the beans was sorghum; this weed is one of the main infesting species in crops irrigated with sorghum in the growing region. This species can show high competition in the crops of beans, because it has a $\mathrm{C} 4$ photosynthetic mechanism and establishes itself quickly in the area with the presence of light; according to Lorenzi (2008), in adulthood it can go over $2 \mathrm{~m}$ high.

Brachiaria plantaginea and Boerhavia diffusa also presented high IVI at stage V3, and this last one was the weed with greater IVI values for cultivars BRSMG Majestoso, BRS Campeiro and BRS Valente. Tavares et al. (2013), when assessing the phytosociology in bean crops in Urutai-GO, saw that the most important species in the weed community were Zea mays and Cyperus rotundus in autumn-winter crops, Ageratum conyzoides and Eleusine indica in spring-summer crops and Digitaria horizontalis and Bidens pilosa in the summer-winter period.

Boerhavia diffusa, which can reach from 0.5 to $1 \mathrm{~m}$ high, is a weed more commonly found in fertile and shaded soils, vegetating mainly in the hot period of the year (Lorenzi, 2008). In turn, B. plantaginea is one of the most aggressive weeds from the Poaceae family, happening in several agricultural areas, and the harm caused may vary according to the size of the crop and the duration of the competition period (Kissmann, 1997).

The dry matter of the weeds in stage V3 ranged from 1.70 to $3.60 \mathrm{~g}$, in cultivars BRS Campeiro and Pérola, respectively (Table 4). In addition to the superior number of specimens found in this stage, they do not present high values of dry matter (DM) because they are in the beginning of their development, showing little competition for water, light, nutrients and space with bean plants.

The number of specimens found in the R8 stage was below the one observed in V3, and cultivars BRS Majestoso, BRS Campeiro and Pérola presented smaller numbers of specimens of weeds in this stage (Table 5). The control of weeds was effective in the reduction of the number of specimens, but some weeds, such as Amaranthus sp. and Euphorbia heterophylla, remained in the area, and other species, such as Chamaesyce hirta, emerged 
Erect habit cultivars
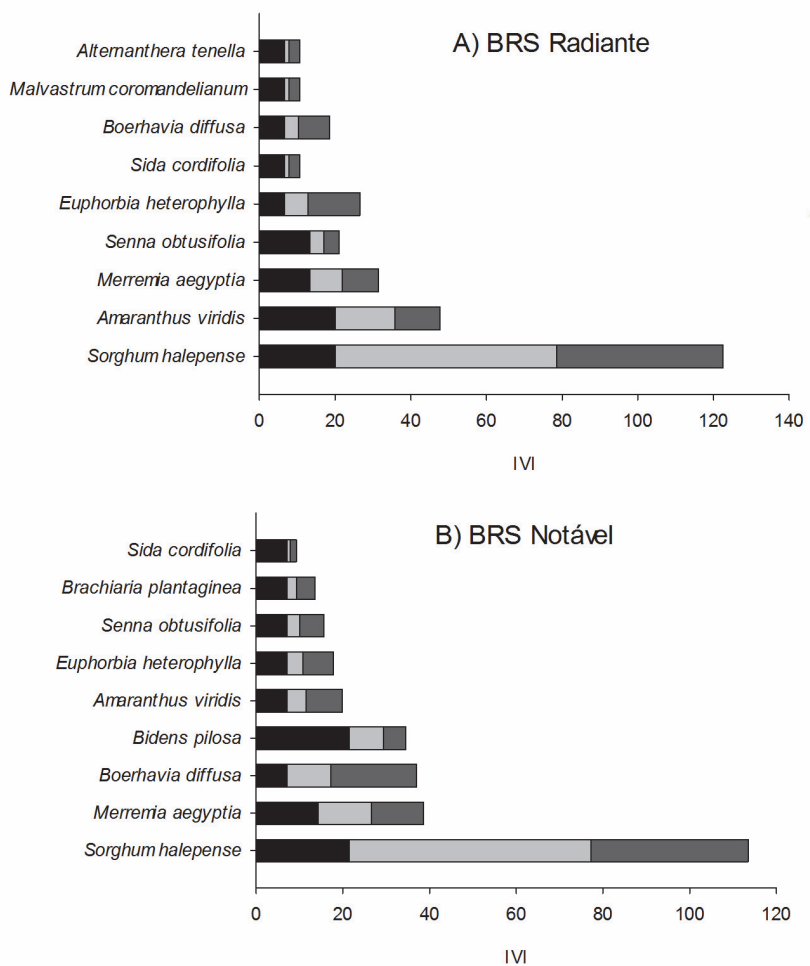

C) BRS Valente
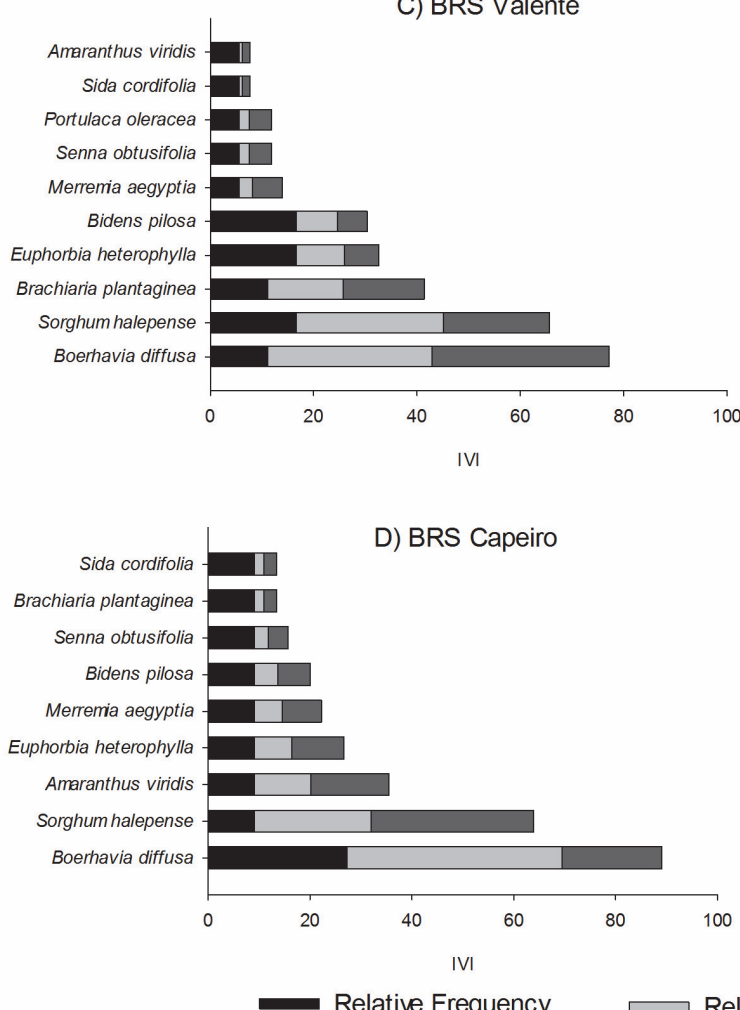

Relative Frequency $\square$ Relative Density

\section{Prostrate and semi erect habit cultivars}
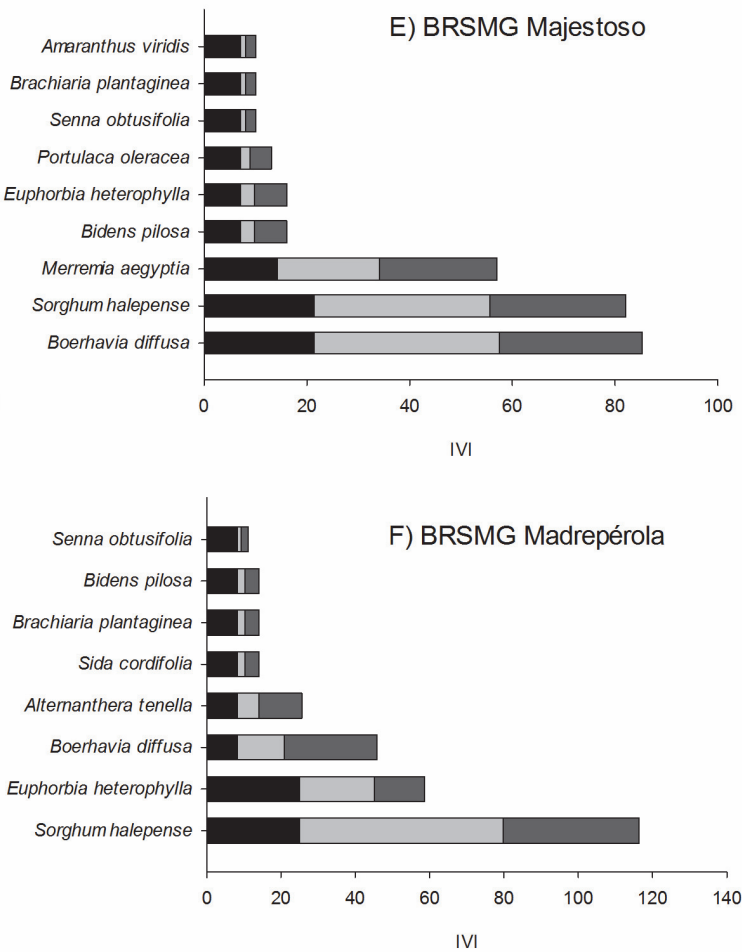

G) Ouro Negro
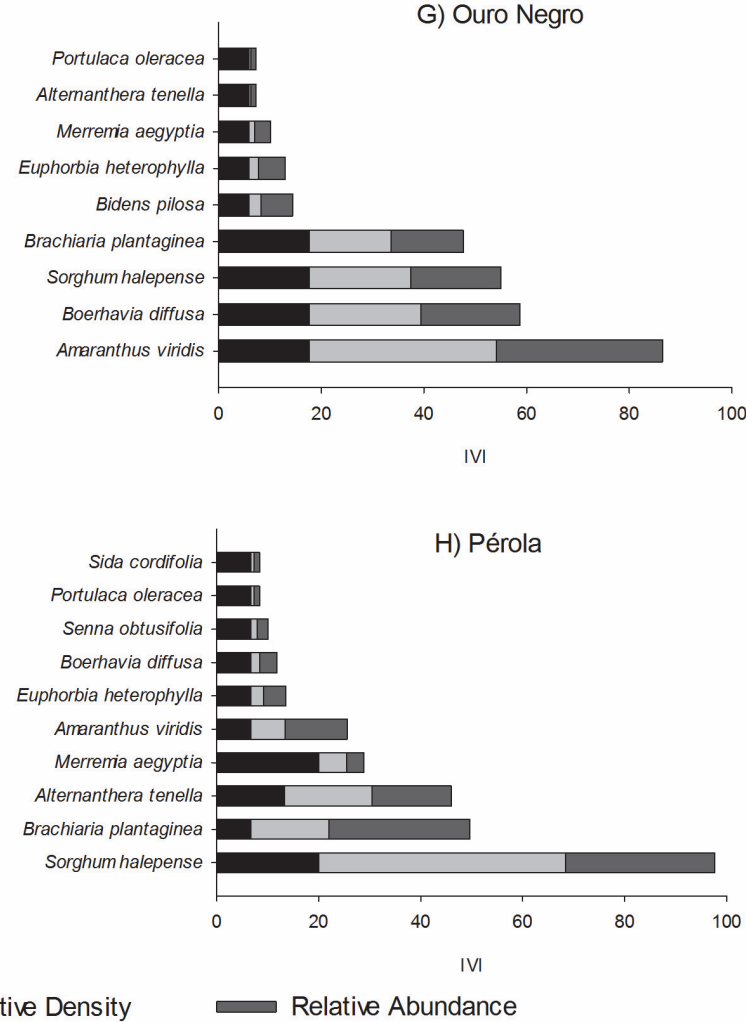

Figure 1 - Importance value index (IVI) of the main weeds found in erect common bean cultivars (left) and semi erect and prostrate cultivars (right) at stage V3, in the autumn-winter crop, in the north of Minas Gerais. Janaúba, 2015. 
after the application of the herbicide. The smaller number of weeds was observed in the more prostrate cultivars, and only two species were found in the Pérola and Ouro Negro cultivars, three in the Madrepérola cultivar and four in the Majestoso cultivar (Figure 2). The size of the cultivars certainly influenced the occurrence of weeds, especially at the R8 stage. Thus, the smaller number of weeds in the more prostrate cultivars is due to the fact that the closing of the area is faster, reducing the amount of light that surpassed the canopy and made difficult the growth of weeds in between the crop rows, which suggests that cultivars with this type of growth have a better competitive efficiency with weeds than more erect cultivars.

According to Santos and Gavilanes (2006), the plant's morphology is a crucial factor regarding the competition capacity of the bean plants with weeds, in which genotypes with growth habits type I and II, with erect habit and little branching, are less competitive when compared to type III genotypes, being those more cultivated and more capable of promoting greater soil coverage. Teixeira et al. (2009), when assessing the competition between bean plants and weeds in function of the type of growth of the cultivars, saw that the more prostrate bean cultivars, Pérola (type II/III) and Aporé (type III), are more competitive with the infesting community of weeds.

Despite the reduction in the number of specimens and species of weeds in flowering, their dry matter was superior to the dry matter at V3 stage, in cultivars BRS Radiante, Madrepérola, BRS Notável and BRS Valente (Table 5). The increase in dry matter might be explained by the higher height of this weed due to its faster development mainly because of their search for light.

Regardless of the bean plant cultivar, Amaranthus viridis was the weed that had higher IVI values (Figure 2), number of specimens and dry matter (Table 5) at the R8 stage. Although it has a $\mathrm{C} 4$ photosynthetic metabolism and has higher lighting demands, this species has shown to be very competitive with beans at this development stage. The species from the Amaranthus genus can cause great losses because they have a high initial growth vigor, efficient root system and seed dormancy, and they can also host plant pathogens (Carvalho and Christoffoleti, 2008).

Barroso et al. (2010), in a study that assessed competitiveness of several species of weeds on beans, in two sowing periods, saw that $A$. viridis showed to be the most aggressive among all, causing harm in the growth and development of beans, with reductions that reached $80 \%$ in the final productivity of the crop. According to Lorenzi (2008), the species from the Amaranthus sp. genus had great importance in crops with low intensity of shade and fertile soils because they are very prolific and have a relatively short cycle, besides being found in great amount in the soil seed bank.

It is seen that the greater similarity index of weeds happened when comparing the erect cultivars to the semi erect and prostrate cultivars in stage V3, obtaining a value of 90.90\% (Table 6). This similarity is explained by the equal condition of cultivation to which all cultivars were subjected in planting, presenting a seed bank in the soil of similar weeds. When the similarity index of erect cultivars was compared to the semi erect and prostrate cultivars in stage $\mathrm{R} 8$, there was a smaller similarity index (58.82\%). Certainly, the size of the bean plants influences the weeds, conditioning the occurrence of weeds with more tolerance to shade in the more prostrate cultivars and weeds that need more light in the more erect cultivars, which are less efficient, in the closing of the area.

The similarity index of the infesting flora in both collection stages of weeds was $64 \%$, which indicates that the control of weeds, as well as the condition of smaller lighting incidence at the R8 stage caused the infesting flora to change in this stage in comparison to stage V3, prevailing species with more tolerance to shading.

The results obtained allowed us to affirm that S. halepense, the weed with greater IVI on stage V3 of the beans, did not happen on stage R8 in none of the cultivars, showing to be a little competitive plant in the absence of light and that the control with herbicides was efficient in the control of this weed. A. viridis, which, with the exception of the Ouro Negro cultivar, presented low values of IVI in 

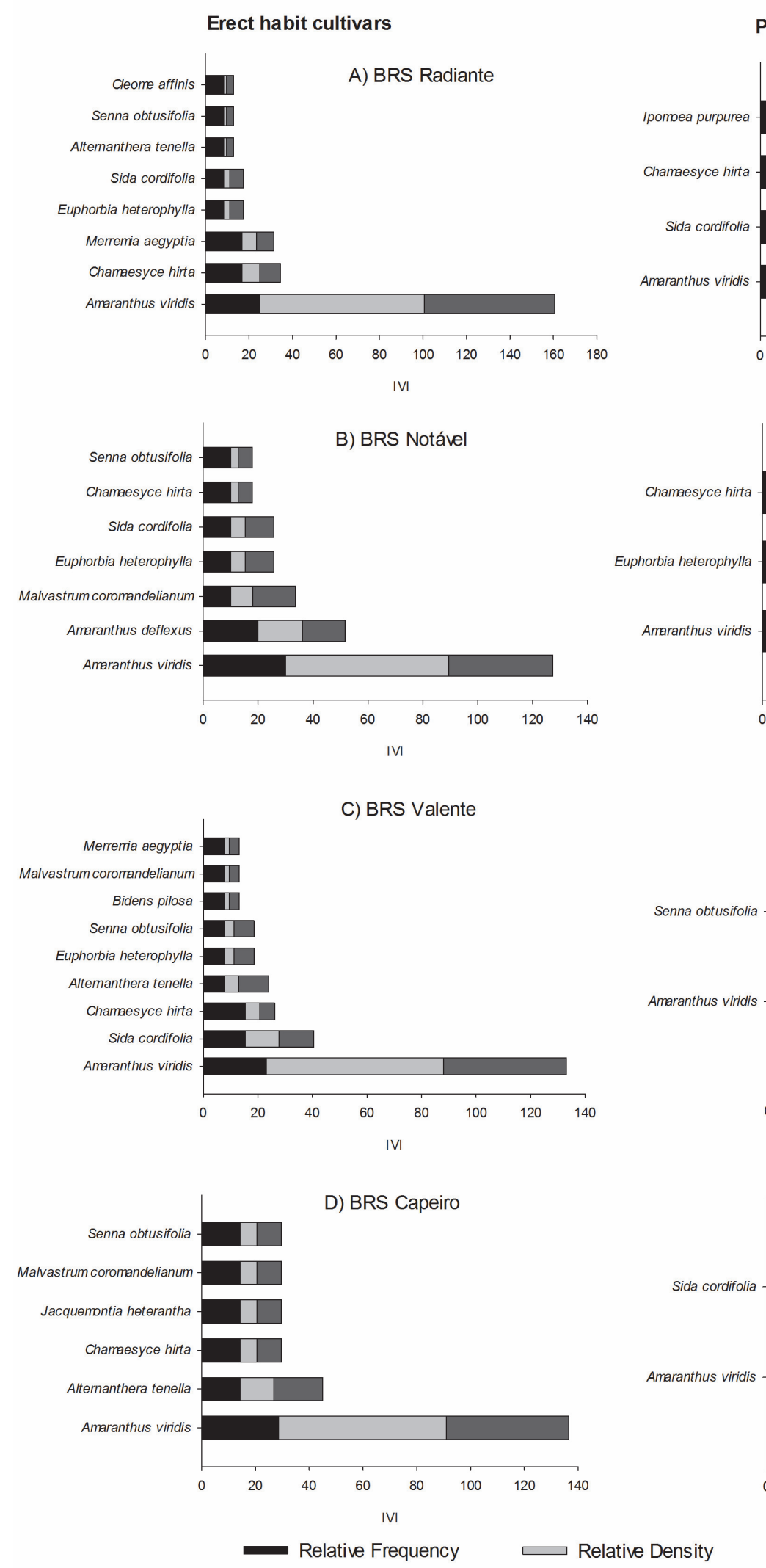

Figure 2 - Importance value index (IVI) of the main plants found in erect common bean cultivars (left) and semi erect and prostrate cultivars (right) at stage R8, in the autumn-winter crop, in the north of Minas Gerais. Janaúba, 2015.

Planta Daninha, Viçosa-MG, v. 34, n. 3, p. 497-507, 2016

\section{Prostrate and semi erect habit cultivars}
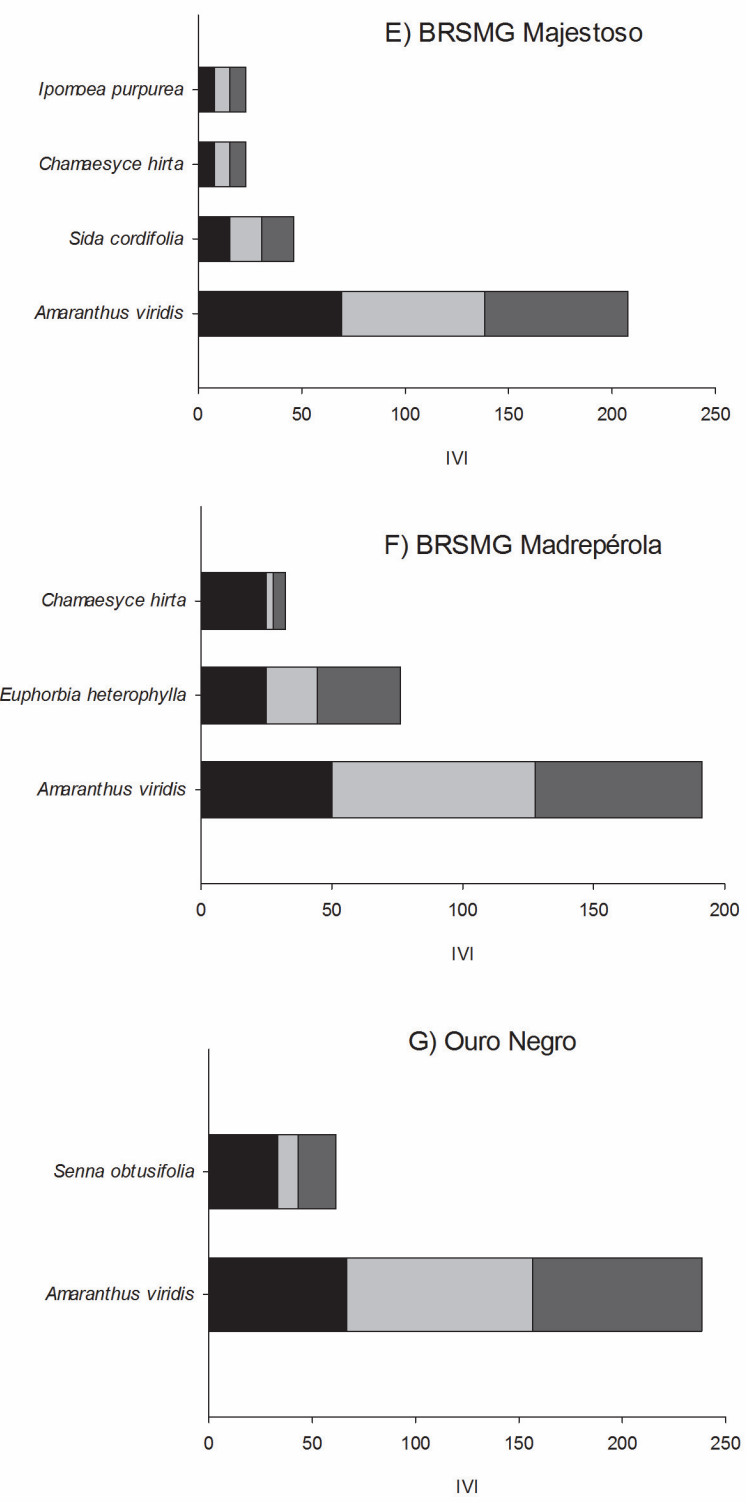

H) Pérola

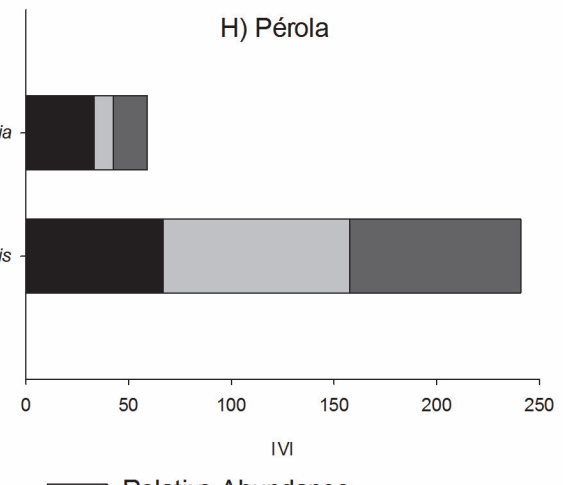


Table 6 - Comparison of the similarity of weeds communities occurring in stages V3 and R8 and in erect, semi erect and prostrate habit. Janaúba, MG. 2015

\begin{tabular}{|l|c|}
\hline \multicolumn{1}{|c|}{ Comparison criteria } & Similarity index (\%) \\
\hline Stage V3 x Stage R8 & 64.00 \\
\hline Erect x Prostrate in Stage V3 & 90.90 \\
\hline Erect x Prostrate in Stage R8 & 58.82 \\
\hline
\end{tabular}

the V3 stage and was the species with greater IVI on stage R8, which indicates it is a high competitive plant in low light conditions.

The more prostrate cultivars are more competitive with weeds, especially in the R8 stage, considering the smaller IVI values obtained in this situation. The smaller similarity index of weeds happened when comparing the cultivars of different sizes in stage R8, suggesting that the weeds occurred in more prostrate cultivars are more competitive in low light conditions.

\section{ACKNOWLEDGMENTS}

To Embrapa Arroz e Feijão, Fapemig, Capes and Banco do Nordeste do Brasil (BNB) for all technological and financial support.

\section{REFERENCES}

Barroso A.A.M., Yamauti M.S., Alves P.L.C.A. Interferência entre espécies de planta daninha e duas cultivares de feijoeiro em duas épocas de semeadura. Bragantia. 2010;69:609-16.

Borchartt L. et al. Períodos de interferência de plantas daninhas na cultura do feijoeiro-comum (Phaseolus vulgaris L.). Rev Cienc Agron. 2011;42:725-34.

Brighenti A.M. et al. Cadastramento fitossociológico de plantas daninhas na cultura de girassol. Pesq Agropec Bras. 2003;38:651-7.

Carvalho S.J.P., Christoffoleti P.J. Competition of Amaranthus species with dry bean plants. Sci. Agricola. 2008;65:239-45
Cobucci T. Manejo e controle de plantas daninhas em feijão. In: Vargas L., Roman E.S. Manual de manejo e controle de plantas daninhas. Bento Gonçalves: Embrapa Uva e Vinho, 2004. p.453-80.

Cruz D.L.S. et al. Levantamento de plantas daninhas em área rotacionada com as culturas da soja, milho e arroz irrigado no cerrado de Roraima. Rev Agro@mbiente On-line. 2009:v.3.

Empresa Brasileira de Pesquisa Agropecuária Embrapa. Dados conjunturais da produção de feijão comum (Phaseolus vulgaris L.) e caupi (Vigna unguiculata (L.) Walp) no Brasil (1985 a 2014): área, produção e rendimento. Santo Antônio de Goiás: Embrapa Arroz e Feijão, 2015. Accessed on: Feb 2016. Available at: http://www.cnpaf.embrapa.br/socioeconomia/index.htm.

Gama J.C.M. Florística e fitossociologia de plantas espontâneas em comunidades antropizadas do cerrado em Minas Gerais [dissertação]. Belo Horizonte:

Universidade Federal de Minas Gerais, 2009.

Kissmann K.G. Plantas infestantes e nocivas. $2^{\mathrm{a}}$. ed. São Paulo: Basf Brasileira, 1997. v.1. p.415-20.

Lorenzi H. Plantas daninhas do Brasil: terrestres, aquáticas, parasitas e tóxicas. $4^{\mathrm{a}}$. ed. Nova Odessa: Instituto Plantarum, 2008. 640p.

Oliveira A.R., Freitas S.P. Levantamento fitossociológico de plantas daninhas em áreas de produção de cana-de-açúcar. Planta Daninha. 2008;26:33-46.

Pitelli R.A. Estudos fitossociológicos em comunidades infestantes de agroecossistemas. J Conserb. 2000;1:17.

Salgado T.P. et al. Interferência das plantas daninhas no feijoeiro carioca. Planta Daninha 2007;25:443-8.

Santi A.L. et al. Phytosociological variability of weeds in soybean Field. Planta Daninha. 2014;2:39-49.

Santos J.B., Gavilanes M.L. Botânica. In: Vieira C., Paula Júnior T.J., Borém A., editores. Feijão. $2^{\mathrm{a}}$. ed. Viçosa, MG: Universidade Federal de Viçosa, 2006. p.41-65.

Tavares C.J. et al. Fitossociologia de plantas daninhas na cultura do feijão. Rev Bras Cienc Agr. 2013;8:27-32.

Teixeira I.R. et al. Competição entre feijoeiros e plantas daninhas em função do tipo de crescimento dos cultivares. Planta Daninha. 2009;27:235-40. 